\title{
A economia cubana no início do século XXI: Avaliação do desempenho e debate sobre o futuro
}

\author{
Carmelo Mesa-Lago \\ University of Pittsburgh
}

\begin{abstract}
Resumo
No início do século 21, a economia cubana parecia continuar em seu longo e lento processo de recuperação, depois da grave crise dos anos noventa. Mas vários fatores negativos surgiram em 2001 e na primeira metade de 2002, como os ataques terroristas de 11 de setembro de 2001; a recessão que começou em março de 2001 e se agravou em setembro; a queda dos preços mundiais do níquel; o furacão Michelle que atingiu a ilha no dia 4 de novembro; o fechamento da base russa de vigilância em Lurdes; a queda do investimento estrangeiro direto e a deterioriação da situação política na Venezuela em 2002. Baseado principalmente em estatísticas e informações de fontes cubanas, este artigo avalia o desempenho econômico e social de Cuba em 2000-2001 e na primeira metade de 2002; a situação neste período é contrastada com a de 1989 (anterior à crise) e de 1993 (o pior ponto da crise).
\end{abstract}

Palavras-chave: Cuba, indicadores sociais, desenvolvimento, desempenho econômico, crise mundial

\begin{abstract}
At the start of the 21st century, the Cuban economy seemed to continue in the long and slow process of recovery after the grave crisis of the 1990s. But several negative factors struck in 2001 and the first half of 2002, including the terrorist attacks of September 11, 2001; the recession that began in March 2001; the fall of the world prices of nickel; the hurricane Michelle that hit the island on November 4; the shut down of the Russian surveillance base in Lourdes; the drop of direct foreign investment, and the economic consequences of the deteriorated political situation in Venezuela. Mainly based on statistics and information from Cuban sources, this paper evaluates Cuban economic and social performance in 2000-2001 and the first half of 2002; the situation in this period is contrasted with that in 1989 (prior to the crisis) and 1993 (the worst point in the crisis).
\end{abstract}

Keywords: Cuba, social indicators, development, economic performance, world crisis. 


\section{Introdução}

No início do novo século, a economia cubana parecia continuar em seu longo e lento processo de recuperação, depois da grave crise dos anos noventa. Mas vários fatores negativos surgiram em 2001 e na primeira metade de 2002: (1) os ataques terroristas de 11 de setembro de 2001 e a guerra no Afeganistão provocaram um declínio drástico do turismo; (2) a recessão que começou em março de 2001 e se agravou em setembro também reduziu as viagens internacionais e cortou as remessas em dólar enviadas por cubanos no exterior; (3) os preços mundiais do níquel caíram $40 \%$ devido à recessão (os preços do açúcar também caíram), que também reduziu a demanda por charutos cubanos; (4) o furacão Michelle atingiu a ilha no dia 4 de novembro, causando danos estimados em 1.866 milhões de pesos, equivalentes a 6,6\% do PIB em 2001; (5) a Rússia fechou a base de vigilância em Lourdes e parou de pagar uma taxa anual de 200 milhões de dólares; (6) o investimento estrangeiro direto despencou em $91 \%$ e graças, em larga medida, à deterioração da economia cubana e à falta de pagamento aos credores, os empréstimos em moeda forte se tornaram mais apertados e caros; e (7) a situação política da Venezuela deteriorou em 2002 e o fornecimento de petróleo foi suspenso. Além disso, a tímida reforma econômica iniciada no começo dos anos noventa e suspensa em 1996 continua paralisada.

Baseado principalmente em estatísticas e informações de fontes cubanas, este artigo avalia o desempenho econômico e social de Cuba em 2000-2001 e na primeira metade de 2002. A situação deste período é contrastada com a de 1989 (anterior à crise) e a de 1993 (o pior ponto da crise), e a análise do desempenho socioeconômico inclui indicadores macroeconômicos, do setor externo, de produção física e trabalhistas/ sociais. Também avalia-se o cumprimento de metas de médio e curto prazo, bem como as perspectivas para 2002, e faz-se um resumo da opinião dos economistas cubanos sobre os problemas atuais e suas sugestões para o futuro.

\section{Desempenho Econômico}

Várias tabelas incluídas neste artigo resumem os principais indicadores econômicos e sociais de Cuba, apresentados por instituições governamentais tais como a Oficina Nacional de Estadísticas (ONE), o Banco Central de Cuba (BCC) e vários ministérios. Outros dados vêm de estudiosos cubanos (cuja produção acadêmica expandiu-se significativamente, tanto em quantidade como em

\footnotetext{
${ }^{1}$ Este artigo é uma ampliação e atualização para 2001-2002 de "The Cuban Economy in 1999-2001: Evaluation of Performance and Debate on the Future", Cuba in Transition, 11. Washington DC: ASCE, 2001: 1-17. Agradeço o apoio da Alexander von Humboldt Stiftung.
} 
qualidade) e ainda dados oficiais da Comissão Econômica para a América Latina e o Caribe (ECLAC) das Nações Unidas. A série começa em 1989, o ano anterior ao início da crise, mostra seu pior ponto em 1993 e a recuperação de 1994-2001 (para uma análise recente das estatísticas cubanas, ver Mesa-Lago, 2001a). Estão feitas comparações entre 1989 e 2001, bem como com a América Latina e o Caribe, sempre que possível. A avaliação do desempenho está dividida em quatro seções principais: macroeconômica, externa, produção física e trabalhista/ social.

\section{A. Indicadores macroeconômicos internos}

1. Crescimento. A Tabela 1 mostra que o PIB diminuiu de $6,2 \%$ em 1999 para 5,6\% em 2000 e 3\% em 2001; a taxa no último ano foi menor do que a média de $4,3 \%$ durante a recuperação de 1994-2000, mas mais alta do que o 1,8\% de 1997-98. A taxa média do PIB cubano de 1999-2001 foi a terceira mais alta da América Latina e do Caribe, logo após a da República Dominicana e de Granada, que estão entre os países menos desenvolvidos da região ${ }^{2}$, e ainda mais, o PIB de Cuba sofreu um declínio de 35\% no período de 1989-1993, o pior desempenho da região. A taxa anual de crescimento do país durante a recuperação de 1994-2000 foi em média de $3,8 \%$, mas para todo o período $1990-2000$, foi de $-1,2 \%$, a mais baixa da região (ECLAC, 2000b) ${ }^{3}$. Em 2001, o nível do PIB de Cuba em preços constantes desde 1981 foi de 17.053 milhões de pesos (ONE, 2001), 19\% abaixo do nível de 1989, que foi de 20.960 milhões de pesos (de acordo com BCC 2001, a diferença para 1989 foi de apenas 15\%). Em 2001, o PIB per capita a preços constantes, em pesos, foi $23 \%$ menor que o de 1989. Seriam necessários seis anos para recuperar o nível absoluto do PIB de 1989 e oito anos para recuperar o nível per capita.

\footnotetext{
2 O BCC (2000; 2001) compara indicadores socioeconômicos cubanos selecionados, quando eles são favoráveis, com os da América Latina: taxas de PIB, inflação, déficit fiscal, mortalidade infantil e desemprego aberto.

${ }^{3}$ A ECLAC deixou de publicar médias de períodos em seu último relatório anual (2001b).
} 
TABELA 1

Indicadores macroeconômicos cubanos: 1989-2001

(em \%)

\begin{tabular}{|c|c|c|c|c|c|c|c|c|c|c|c|}
\hline Indicadores & 1989 & 1993 & 1994 & 1995 & 1996 & 1997 & 1998 & 1999 & 2000 & 2001 & $\begin{array}{c}\% 2001 \\
1989\end{array}$ \\
\hline $\begin{array}{l}\text { Taxa de } \\
\text { crescimento } \\
\text { do PIB }^{\mathrm{a}}\end{array}$ & 1.2 & -14.9 & 0.7 & 2.5 & 7.8 & 2.5 & 1.2 & 6.2 & 5.6 & 3.0 & $-19^{d}$ \\
\hline $\begin{array}{l}\text { PIB per capita } \\
\text { (pesos) }^{\mathrm{a}}\end{array}$ & 1,976 & 1,172 & 1,175 & 1,201 & 1,290 & 1,317 & 1,327 & 1,405 & 1,478 & 1,518 & -23 \\
\hline $\begin{array}{l}\text { Formação de } \\
\text { capital bruto } \\
\text { /PIB }^{\mathrm{a}}\end{array}$ & 26.7 & 5.4 & 5.5 & 7.2 & 8.2 & 9.5 & 9.4 & 10.3 & 13.2 & 13.3 & -51 \\
\hline $\begin{array}{l}\text { Taxa de } \\
\text { inflação }\end{array}$ & n.d. & 19.7 & 25.7 & -11.5 & -4.9 & 1.9 & 2.9 & -2.9 & -2.3 & -1.4 & n.d. \\
\hline $\begin{array}{l}\text { Liquidez } \\
\text { monetária }\end{array}$ & 21.6 & 73.2 & 51.8 & 42.6 & 42.0 & 41.1 & 40.6 & 38.8 & 37.9 & 41.0 & +90 \\
\hline $\begin{array}{l}\text { Equilíbrio } \\
\text { fiscal/PIB }\end{array}$ & -7.2 & -33.5 & -7.4 & -3.5 & -2.5 & -2.0 & -2.3 & -2.4 & -2.4 & -2.5 & -62 \\
\hline
\end{tabular}

${ }^{a}$ A preços constantes de $1981 .{ }^{b}$ Variação anual do IPC. ${ }^{c}$ A preços correntes. ${ }^{d}$ Baseado no PIB a preços constantes de 1981, em milhões de pesos: 20.960 em 1989 e 16.552 em 2000.

Fontes: CCE 1991; ONE 1999, 2000, 2001; BCC 2000, 2001, 2002; ECLAC 2001a, 2001b, 2002b; PérezVillanueva 2002; Triana 2002.

2. Formação de capital. A formação de capital bruto como porcentagem do PIB encolheu de 26,7\% para 5,4\% em 1989-1993, mas cresceu desde 1995 e atingiu 13,3\% em 2001, embora esteja ainda 51\% abaixo do nível de 1989 (ECLAC, 2001b estima que o investimento interno bruto foi em média $8,4 \%$ do PIB em 1997- 2001). Um estudioso cubano adverte que uma forte recuperação econômica exigiria taxas de investimento semelhantes às de 1975 e 1989, ou seja, 25\% do PIB (Marquetti, 2000). Outro estudioso reconhece também o baixo nível de investimento atual e que, para aumentá-lo, seria necessário expandir mais o PIB, em vez de mudar a estrutura de investimento/ consumo, visto que este último não pode mais ser reduzido (Triana, 2001).

3. Estabilidade. A inflação (baseada no índice de preços ao consumidor IPC) atingiu um pico de 25,7\% em 1994 e transformou-se em deflação: -2,9\% em 1999, -2,3\% em 2000 e -1,4\% em 2001. Esses números são, porém, questionáveis por quatro motivos: (1) Cuba jamais publicou informações sobre a cesta de bens e serviços usada para o cálculo do IPC; (2) 1981 foi usado durante vinte anos como base para preços constantes, apesar das críticas do exterior pelo motivo de ter sido 
um ano anormal (de alta inflação) ${ }^{4}$; (3) a variação do IPC (negativa) é significativamente diferente do deflator implícito para o PIB (positivo), que cresceu: 0,4\% em 1999, 0,1\% em 2000 e 1\% em 2001 (ECLAC, 2001a); e (4) a “liquidez monetária" foi reduzida de 11 para 9.2 bilhões de pesos em 1994-95 (de 73,2\% para 42,6\% do PIB), mas aumentou de novo em 1996-2001, superarando 12 bilhões de pesos $(45,6 \% \text { do } P I B)^{5}, 3,5$ vezes o nível de 1989 (Tabela 2). Uma questão intrigante é como houve deflação em 1999-2001 se, ao mesmo tempo, o deflator do PIB e a liquidez monetária aumentaram.

\section{Tabela 2}

Liquidez monetária cumulativa da população cubana: 1989-2001 (em milhões de pesos correntes e \% do PIB)

\begin{tabular}{|c|c||c||}
\cline { 2 - 3 } \multicolumn{1}{c|}{} & $\begin{array}{c}\text { Liquidez monetária } \\
\text { cumulativa }^{\mathrm{a}}\end{array}$ & $\begin{array}{c}\% \\
\text { do PIB }\end{array}$ \\
\hline 1989 & 4,164 & 21.6 \\
\hline 1990 & 4,986 & 25.4 \\
\hline 1991 & 6,564 & 40.4 \\
\hline 1992 & 8,362 & 56.1 \\
\hline 1993 & 11,043 & 73.2 \\
\hline 1994 & 9,944 & 51.8 \\
\hline
\end{tabular}

\begin{tabular}{|c|c|c||}
\cline { 2 - 3 } \multicolumn{1}{c|}{} & $\begin{array}{c}\text { Liquidez monetária } \\
\text { cumulativa }^{\text {a }}\end{array}$ & $\begin{array}{c}\% \\
\text { do PIB }\end{array}$ \\
\hline \hline $\mathbf{1 9 9 5}$ & 9,251 & 42.6 \\
\hline $\mathbf{1 9 9 6}$ & 9,534 & 42.0 \\
\hline $\mathbf{1 9 9 7}$ & 9,441 & 38.3 \\
\hline $\mathbf{1 9 9 8}$ & 9,710 & 37.5 \\
\hline $\mathbf{1 9 9 9}$ & 9,902 & 35.9 \\
\hline $\mathbf{2 0 0 0}$ & 10,490 & 35.1 \\
\hline $\mathbf{2 0 0 1}$ & $12,478^{\text {b }}$ & 45.7 \\
\hline
\end{tabular}

aiquidez monetária.

b Soma da circulação monetária e todas as contas de poupança bancárias.

Fontes: CEE 1991; ONE 1999, 2000, 2001; BCC 2000, 2001, 2002; ECLAC 2002b.

O déficit fiscal enquanto porcentagem do PIB foi cortado de 33,5\% para $2 \%$ em 1993-1997, uma realização significativa, mas subiu para 2,4\% em 2000 e 2,5\% em 2001, números pouco abaixo da média da América Latina naqueles dois anos:

\footnotetext{
${ }^{4}$ Em 2001, o crescimento do PIB a preços constantes foi baseado no ano de 1997, mas não há séries anteriores disponíveis (ECLAC, 2002b).

${ }^{5}$ Triana (2001) observa que a estimativa da liquidez exclui a circulação em dólares; portanto, a porcentagem deve ser maior.
} 
$2,7 \%$ e 3,1\% (ECLAC, 2001b). Um componente importante do déficit é o subsídio fiscal a empresas estatais ineficientes (concentradas nos setores açucareiro e agrícola), embora ele tenha diminuído em 2001.

\section{B. Setor externo}

1. Balança comercial. Os principais indicadores do setor externo estão na Tabela 3. Depois de um declínio dramático de 79\% em 1989-1993, o valor das exportações (bens) aumentou em 61\% em 1993-96, mas declinou e estacionou a partir de então: o valor das exportações foi de 1.67 bilhões de pesos em 2000 e 1.66 em 2001, ainda 69\% abaixo do nível de 1989. A importação de bens caiu $75 \%$ em 1989-1993, mas cresceu constantemente a partir de então, atingindo 4.83 bilhões de pesos em 2000 e 4.78 bilhões em 2001, ainda $41 \%$ menos do que em 1989. Com as importações se expandindo mais rapidamente do que as exportações, o déficit da balança comercial de bens saltou quase quatro vezes no período 1993-2001 e atingiu o recorde histórico de 3.15 bilhões de pesos em 2000 (3.12 bilhões em 2001), 15\% mais alto do que o déficit de 1989. Diz um economista cubano: "Esses resultados confirmam a tradicional fraqueza do setor externo cubano que depois de mais de dez anos de transformação econômica foi incapaz de mudar substancialmente o padrão da inserção externa no comércio mundial de bens" (Triana, 2002, p.13). Ademais, há uma importante diferença entre 1989 e 2001: para cobrir o déficit, Cuba não se beneficia mais dos generosos empréstimos automáticos de longo prazo da União Soviética, que eram feitos a juros muito baixos e jamais pagos. Agora Cuba tem de apelar para empréstimos de curto prazo de bancos estrangeiros e outras instituições financeiras, que cobram altas taxas de juros (ver adiante).

O déficit no comércio de mercadorias foi parcialmente compensado com um superávit substancial nos serviços, principalmente no turismo, mas a balança de conta corrente foi negativa: -462 milhões de pesos em 1999 ( $1,7 \%$ do PIB), -687 milhões de pesos em 2000 (2,3\% do PIB) e -650 milhões em 2001 (2,1\% do PIB); estes foram os dois déficits mais altos desde o final dos anos oitenta. $O$ déficit em conta corrente, por sua vez, foi parcialmente compensado com "transferências líquidas", principalmente remessas de cubanos no exterior, que subiram (em milhões de pesos) de zero em 1989 para 799 em 1999, 842 em 2000 e 813 em 2001. Mas os pagamentos do principal da dívida e juros, combinados com remessa de lucros de investidores estrangeiros, aumentaram a balança negativa (em milhões de pesos): -514 em 1999, -693 em 2000 e -670 em 2001 (ECLAC, 2002b; para estimativas diferentes, ver BCC, 2000, 2001, 2002; Pérez-López, 2002). 
OPINIÃO PÚBLICA, Campinas, Vol. IX, no 1, 2003, pp. 190-223

Tabela 3

Indicadores do setor externo cubano: 1989-2001

\begin{tabular}{|c|c|c|c|c|c|c|c|c|c|c|c|}
\hline Indicadores & 1989 & 1993 & 1994 & 1995 & 1996 & 1997 & 1998 & 1999 & 2000 & 2001 & $\begin{array}{c}\% 2001 \\
1999\end{array}$ \\
\hline $\begin{array}{l}\text { Exportações } \\
\text { (bilhões de } \\
\text { pesos) }\end{array}$ & 5.4 & 1.1 & 1.3 & 1.5 & 1.9 & 1.8 & 1.5 & 1.4 & 1.7 & 1.7 & -69 \\
\hline $\begin{array}{l}\text { Importações } \\
\text { (bilhões de } \\
\text { pesos) }\end{array}$ & 8.1 & 2.0 & 2.1 & 2.8 & 3.6 & 4.1 & 4.2 & 4.3 & 4.9 & 4.8 & -41 \\
\hline $\begin{array}{l}\text { Balança } \\
\text { comercial } \\
\text { (bilhões pesos) }\end{array}$ & -2.7 & -0.9 & -0.8 & -1.3 & -1.7 & -2.3 & -2.7 & -2.9 & -3.2 & -3.1 & +15 \\
\hline $\begin{array}{l}\text { Termos de } \\
\text { comércio } \\
(1989=100)\end{array}$ & 100.0 & 54.4 & 65.9 & 71.2 & 65.1 & 67.0 & 64.2 & 53.2 & 47.4 & 47.5 & -52 \\
\hline $\begin{array}{l}\text { Dívida externa } \\
\text { (bilhões US\$) }\end{array}$ & 6.2 & 8.8 & 9.1 & 10.5 & 10.5 & 10.1 & 11.2 & 11.1 & 11.0 & 10.9 & +77 \\
\hline $\begin{array}{l}\text { Investimento } \\
\text { externo } \\
\text { (bilhões US\$) }\end{array}$ & n.d. & n.d. & n.d. & 2.1 & n.d. & n.d. & 2.2 & n.d. & $2.2^{b}$ & $2.5^{b}$ & n.d. \\
\hline $\begin{array}{l}\text { Taxa de } \\
\text { câmbio (pesos } \\
\text { por } 1 \text { US\$) }\end{array}$ & 7 & 78 & 95 & 32 & 19 & 23 & 21 & 20 & 21 & 26 & +214 \\
\hline
\end{tabular}

a Em 1989-1994 taxa do mercado negro; em 1995-2001 taxa de câmbio anual média em agências estatais (CADECA).

b "Investimento desembolsado" em vez de "investimento comprometido" que era de US $\$ 4.3$ bilhões em 2000 e US\$5 bilhões em 2001.

Fontes: Três primeiras colunas CCE 1991; ONE 1999, 2000, 2001; BCC 2000, 2001, 2002. Termos de comércio de ECLAC 2002b (a série para 1995-2001 foi mudada). Investimento externo de Martínez 1998, Rodríguez 2000 , 2001.

2. Termos de comércio. Os termos de comércio deterioraram em 52 pontos percentuais em 1989-2001. Em 1999, o preço do açúcar caiu um terço enquanto o preço do petróleo subiu 2,5 vezes, provocando uma deterioração de $18 \%$ nos termos de comércio (BCC, 2000). Em 2000, o aumento dos preços do petróleo significou US\$ 500 milhões a mais por um volume similar importado em 1999, e o aumento dos preços do açúcar e do níquel não compensou isso, levando a uma deterioração de $22 \%$ nos termos de comércio (BCC, 2001). Em 2001, os preços do níquel diminuíram $40 \%$ e os do açúcar também declinaram, ficando abaixo do nível de 2000 (os preços das principais exportações caíram 25\%); os preços do petróleo foram altos na primeira metade de 2001 , declinaram na segunda metade e subiram no primeiro trimestre de 2002 (os preços das importações diminuíram apenas 8\%), resultando em uma pequena deterioração nos termos de comércio. 
Em outubro de 2000, o país assinou um acordo de comércio com a Petróleos da Venezuela (PDVSA) que compensou um pouco seus termos de comércio negativos. Em 1999, a Venezuela foi o quarto parceiro comercial de Cuba, na frente da Rússia, e saltou para primeiro lugar em 2000: (a) Cuba recebia 53 mil barris de petróleo diários, o equivalente a três milhões de toneladas anuais, que atendiam $35 \%$ das necessidades internas (8,6 milhões de toneladas); (b) cerca de $80 \%$ do fornecimento era pago a preços do mercado mundial em 90 dias, os $20 \%$ restantes, no período de cinco a vinte anos, com base no preço anual médio daquele período, e um quinto disso com serviços médicos, esportivos e outros; (c) a PDVSA arcava com todos os custos, seguros e transporte do petróleo; e (d) Cuba recebia de facto um desconto de $25 \%$ no preço e o acordo significaria uma transferência de US $\$ 2,6$ bilhões para a ilha nos cinco anos do contrato (que pode ser prorrogado para dez anos). Além disso, dentro do que o acordo permite, Cuba estava revendendo o petróleo venezuelano a preços de mercado, obtendo um lucro considerável (Montiel Ortega, 2001; Rodríguez Castellón, 2001). Mas, como Cuba não pagou o petróleo entregue nos últimos três meses de 2001 (uma dívida de US\$ 95 milhões), a PDVSA suspendeu as entregas, o que provocou a demissão de seu principal diretor pelo presidente Hugo Chávez. No entanto, Chávez ficou enfraquecido pelo golpe de estado de abril de 2002, a dívida de Cuba subiu para 140 milhões e a suspensão das entregas continuou em junho de 2002 (Hoag, 2002; "Quiet Deals..." 2002; Uribe, 2002).

3. Composição do comércio. A concentração das exportações no açúcar diminuiu constantemente, de $73 \%$ para $27 \%$ do total do valor exportado em 1989 2000, em conseqüência da queda na quantidade e no valor do açúcar exportado (os dados para 2001 não estão disponíveis). O níquel foi o único produto de exportação cuja participação foi elevada no período, devido ao aumento em quantidade e preço, enquanto a cota - e, na maior parte dos casos, o volume - de tabaco, peixe, frutas cítricas e rum diminuiu ${ }^{6}$. A composição das importações também mostrou algumas diferenças importantes em 1989-2000: a dependência de alimentos, gorduras e bebidas importadas aumentou de $13 \%$ para $16 \%$, enquanto a de manufaturas subiu de $14 \%$ para $26 \%$; ao contrário, as dependências de máquinas e veículos de transporte diminuíram de $31 \%$ para $25 \%$ e de combustíveis, de $32 \%$ para $24 \%$, depois de um pico de 38\% em 1994 (CCE, 1991; ONE, 1999, 2000, 2001). Ambas as tendências são indicadores claros da diminuição da auto-suficiência do país em alimentos e de seu processo de desindustrialização.

\footnotetext{
${ }^{6}$ Monreal (2001, p. 19) deixa isso bem claro: “O declínio da participação do açúcar no total das exportações foi resultado da crise na indústria açucareira, e não do crescimento de outros setores de exportação".
} 
4. Parceiros comerciais. Em 1989, cerca de $79 \%$ do comércio de Cuba era com a URSS e os países do leste europeu, mas depois do colapso do bloco socialista, a ilha diversificou bastante seus parceiros de comércio. Em 2000, os principais parceiros eram: Venezuela (14\%, um aumento de $8 \%$ em relação a 1999); Espanha (13\%), Canadá (9\%), Holanda e China (8\%), Rússia (7\%, uma queda dos $65 \%$ com a URSS em 1989), México, França e Itália (5\% cada um) (BCC, 2001). Cuba é o único país da América Latina e do Caribe que não é membro pleno de qualquer associação comercial regional (CACM, CAN, CARICOM, MERCOSUL) e foi excluído das negociações da ALCA. Em 2000, entrou para o grupo da Ásia, Caribe e Pacífico (ACP) e, com base nisso, poderia tornar-se membro do Acordo de Cotonou e receber ajuda da UE. Contudo, o país não concordou com as condições da UE sobre direitos humanos e em 2000, quando os países europeus votaram contra a ilha na Comissão de Direitos Humanos da ONU, Cuba decidiu não assinar o acordo. Em dezembro de 2001, a UE reabriu o diálogo com as autoridades cubanas, mas decidiu terminar com a ajuda humanitária em março de 2002 e transferir cerca de US\$ 13 milhões para assistência técnica oferecida por especialistas europeus a projetos de desenvolvimento e reformas orientadas para o mercado. De outro lado, a ilha ganhou status de observador na CARICOM, mas o comércio com os outros membros é minúsculo (León 2001; “La UE..." 2002). O embargo americano foi levemente suavizado, permitindo que a ilha comprasse alimentos, mas o governo cubano rejeitou isso devido à falta de facilidades de crédito.

5. Dívida externa. A dívida em moeda forte estrangeira saltou de US\$6,2 para US\$ 11,2 bilhões em 1989-1998 (devido principalmente à acumulação de juros não pagos) e declinou levemente para US\$ 11,1 bilhões em 1999, US\$ 10,96 em 2000 e US\$ 10,89 bilhões em 2001, graças à depreciação de moedas que compunham a maior parte dessa dívida em relação ao dólar. Cerca de três quartos da dívida venceram e não foram pagos (BCC, 2001). Em 1986, Cuba suspendeu os pagamentos da dívida junto ao principal credor, o Clube de Paris, e apesar das negociações em andamento, em maio de 2002 ainda não havia um acordo com o Clube e, portanto, Cuba não recebia novos empréstimos. A dívida com a Rússia e os antigos países socialistas da Europa oriental, bem como a extinta CMEA, não foi paga e Cuba também não chegou a um acordo sobre as quantias a serem reembolsadas, supostamente porque "elas não são conversíveis em moeda forte [...] e aqueles países unilateralmente não cumprem os termos e as condições daquela dívida" (BCC, 2000, p.38). Em 1999, 80\% das importações foram financiados com empréstimos externos, $70 \%$ com prazo de um ano ou menos, e com altas taxas de juros, que significaram um fardo pesado para as finanças da ilha (BCC, 2000). Em 1996-97, foram recebidos empréstimos de um ano de bancos estrangeiros para 
financiar a colheita de açúcar (cerca de US\$500 milhões), mas os juros foram bastante altos e o ganho líquido da produção açucareira, em queda, foi menor do que o valor do empréstimo mais os juros. O fracasso da safra de 1997 levou a menos crédito externo em 1998; com uma safra um pouco maior em 1999-2000, foi possível conseguir US\$500 milhões em crédito, mas a fraca colheita de 2001 piorou a situação de novo (Mesa-Lago, 1998; Triana, 2000).

Em 1999-2000, negociações bilaterais com credores do Reino Unido, da Bélgica e do J apão resultaram em acordos. Cuba não pôde pagar sua dívida (US\$ 175 milhões) para com seu principal financiador europeu, a francesa COFACE, no final de 2000, e conseguiu postergá-la para junho de 2001, mas não tendo novamente como pagá-la, a linha de crédito foi fechada. Em setembro, também deixou de pagar credores da Espanha, África do Sul e Chile. O acordo da dívida assinado em 1999 com o Japão, principal credor, também parece estar em dificuldades: a partir de 2003, Cuba precisa começar a pagar US\$ 769 milhões aos credores privados japoneses (Frank, 2002a). Em fevereiro de 2002, o Ministro do Comércio Exterior cubano pediu a vários credores estrangeiros a organização de um consórcio para reestruturar cerca de US\$ 150 milhões em empréstimos ("Balance...", 2002); na verdade, parte dessa dívida fora anteriormente reestruturada de curto para médio prazo devido à incapacidade de Cuba pagar desde outubro de 2001; as chances de obter novos créditos - que a ilha precisa desesperadamente - diminuíram bastante. No final de 2001, o vice-presidente Carlos Lage declarou que a dificuldade mais importante que Cuba enfrentaria em 2002 seria o acesso à moeda forte. Diante de tudo isso, o fato de Cuba pagar US\$ 35 milhões em dinheiro para comprar produtos agrícolas americanos pode ser uma isca para obter crédito que terá o mesmo destino do de outros credores.

6. Investimento externo. O investimento externo cumulativo desde 1990 foi oficialmente declarado como sendo de US\$ 2 bilhões em 1995 e US\$ 2,2 bilhões em 1998, praticamente estagnado. Também foram declarados US\$ 4,3 bilhões em 2000 e US\$ 5 bilhões em 2001 (Triana, 2001), o dobro dos números anteriores, mas eles não se referem a investimentos efetivos e sim prometidos. De acordo com a ECLAC (2001a), somente metade dos cinco bilhões foi desembolsada. O investimento externo direto caiu 91\% em 2000-2001, de US\$ 448 milhões para US\$ 38,9 milhões. Em julho de 2002, a União Européia entregou um documento de quinze páginas ao vice-presidente Carlos Lage, queixando-se das seguintes práticas governamentais: excesso de despesas indiretas, custos bancários e alfandegários; mudança unilateral de acordos de joint-ventures em favor de Cuba; pagamentos de salários ao governo cubano em dólares, enquanto a força de trabalho é paga em pesos, à taxa de câmbio oficial (ao par, enquanto a taxa CADECA é de 26 para 1); obrigação dos executivos e altos funcionários estrangeiros de renovar 
freqüentemente vistos e permissões de trabalho e criação de obstáculos desnecessários (Reuters, 2002).

7. Taxas cambiais. A taxa de câmbio oficial do peso em relação ao dólar continua ao par, mas as casas de câmbio estatais (CADECA) decidiram em 1995 pagar uma taxa mais realista. A taxa do peso em relação ao dólar deteriorou de 7 para 95 em 1989-1994, valorizou-se até atingir 19 em 1996, caiu para 21 em 2000 e 26 em 2001 (ECLAC, 2002b). O Banco Central atribuiu a depreciação a uma diminuição de oferta de moeda forte no último trimestre de 2001, que forçou o aumento da liquidez monetária (BCC, 2002). Um economista cubano disse que o câmbio seria de 40 pesos ou mais por dólar se o governo não impusesse um congelamento na taxa cambial (Frank, 2002b). Alguns estudiosos cubanos sustentam que a manutenção de uma paridade artificial é danosa para a economia cubana e defendem a convertibilidade baseada no mercado (ver última seção deste artigo).

8. Turismo. O número de turistas cresceu de 2770 em 1989 para 1.773 .986 em 2000, mas estagnou em 1.774.541 em 2001 (11\% abaixo da meta de dois milhões). A receita bruta cresceu 11,5 vezes, de 168 para 1,948 milhões de dólares em 1989-2000, mas declinou 5\% em 2001, para US\$ 1,846 milhões (BCC, 2002). O problema é que os dados sobre o custo de inputs importados, que devem ser deduzidos da receita bruta para calcular a receita líquida, não são oficialmente publicados. A Tabela 4 é uma tentativa, confessamente especulativa, de calcular o custo dos inputs importados em 1992-2000, baseada em estimativas feitas por estudiosos cubanos em alguns anos. A receita líquida aumentou de 99 para 1,182 milhões no período, mas essas estimativas são discutíveis. Por exemplo, o dado para 2000 baseia-se em uma declaração do Banco Central no sentido de que $61 \%$ dos inputs para turismo foram produzidos internamente, deixando implícito que $39 \%$ foram importados (BCC, 2001, p.25). Contudo, Miguel Figueras explicou a Claes Brundenius em Havana que $61 \%$ eram a receita bruta de moeda forte de entidades turistas e Brundenius calculou que a receita líquida era de $70 \%$. O ministro da Indústria Ibrahim Ferradaz (citado em Muñoz, 2001) declarou que, em 2000, "o custo por dólar de receita [na indústria do turismo] era de 0,78 centavos [...] quase o mesmo que em 1999". Se isso está correto, então o custo dos inputs importados em 1999-2000 não foi 39\%, mas 78\%, e a receita líquida daqueles anos deveria ser 418 e 427 milhões de pesos, respectivamente. A citação de Ferradaz foi esclarecida por Figueras: $78 \%$ se referiam a todos os custos envolvidos na indústria do turismo, incluindo salários, depreciação e inputs (Brundenius, 2002b).

De qualquer modo, um estudioso cubano adverte que o setor de turismo é 
um grande importador e que o país precisará produzir alguns dos inputs necessários a essa indústria, caso contrário, com a expansão planejada, Cuba teria de importar US\$ 3 bilhões - equivalente ao déficit no comércio de mercadorias de 2000 (Pérez Villanueva, 2000). Outros problemas com que se defronta a indústria são: (a) no final de 2001, vinte hotéis de um total de 225 estavam fechados, assim como um terço dos 36 mil quartos, devido ao declínio no turismo; (b) embora existam séries contraditórias sobre a taxa de ocupação dos apartamentos de turismo internacional (ECLAC, 2000; BCC, 2000; ONE, 2001), houve um declínio de $78 \%$ para $74 \%$ em 1997-2000, problema agravado depois de setembro de 2001 , devido à queda no fluxo de turistas, levantando a questão de como os novos quartos serão preenchidos; e (c) os gastos médios, estadias em hotéis e recibos para visitantes declinaram desde a metade dos anos noventa (Espino, 2001).

\section{Tabela 4}

Estimativas aproximadas de receita líquida do turimo: 1992-2000 (em milhões de pesos)

\begin{tabular}{||c|c|c|c|c|c|c|c|c||c||}
\cline { 2 - 10 } \multicolumn{1}{c|}{} & 1992 & $\mathbf{1 9 9 3}$ & $\mathbf{1 9 9 4}$ & $\mathbf{1 9 9 5}$ & $\mathbf{1 9 9 6}$ & $\mathbf{1 9 9 7}$ & $\mathbf{1 9 9 8}$ & $\mathbf{1 9 9 9}$ & $\mathbf{2 0 0 0}$ \\
\hline \hline Receita bruta & 550 & 720 & 850 & 1,100 & 1,380 & 1,515 & 1,759 & 1,901 & 1,948 \\
\hline $\begin{array}{c}\text { Custo de } \\
\text { importações }\end{array}$ & 82 & 77 & 72 & 67 & 63 & 60 & 55 & 50 & 39 \\
\hline $\begin{array}{c}\text { Receita líquida } \\
\text { (\%) }\end{array}$ & 18 & 23 & 28 & 33 & 37 & 40 & 45 & 50 & 61 \\
\hline $\begin{array}{c}\text { Receita líquida } \\
\text { estimada }\end{array}$ & 99 & 165 & 238 & 363 & 510 & 606 & 792 & 950 & 1,182 \\
\hline
\end{tabular}

Fontes: Receita bruta de CCE 1991; ONE 1999, 2000, 2001; BCC 2001. Custo estimado das importações: 1992 de Gutiérrez Castillo 2000 (ele diz que a porcentagem aumentou gradualmente para atingir 54\% em 1999 e esperados 60\% in 2000); 1999 de Marquetti 2000; 2000 de Del Barro 2001 baseado em BCC 2001; o resto são interpolações do autor.

\section{Produção física}

O desempenho da produção física de produtos essenciais da economia cubana (exportações, energia, alimentos e manufaturas) é apresentado na Tabela 5. Com exceção do petróleo, níquel e charutos, a produção foi menor em 2001 do que em 1989. 
OPINIÃO PÚBLICA, Campinas, Vol. IX, no 1, 2003, pp. 190-223

\section{Tabela 5}

Indicadores cubanos de produção física: 1989-2000

(milhares de toneladas)

\begin{tabular}{|c|c|c|c|c|c|c|c|c|c|c|c|}
\hline Indicadores & 1989 & 1993 & 1994 & 1995 & 1996 & 1997 & 1998 & 1999 & 2000 & 2001 & $\begin{array}{c}\% \\
2001- \\
1989\end{array}$ \\
\hline Açúcar & 8,121 & 4,246 & 4,016 & 3,258 & 4,528 & 4,252 & 3,229 & 3,783 & 4,059 & 3,532 & -56 \\
\hline Níquel & 47 & 30 & 27 & 43 & 54 & 62 & 68 & 66 & 71 & 76 & +62 \\
\hline Petróleo & 718 & 1,107 & 1,299 & 1,471 & 1,476 & 1,462 & 1,678 & 2,136 & 2,695 & $2,773^{b}$ & +286 \\
\hline Eletricidade $^{a}$ & 16 & 11 & 12 & 12 & 13 & 14 & 14 & 14 & 15 & 15 & -6 \\
\hline Cimento & 3,759 & 1,049 & 1,085 & 1,456 & 1,438 & 1,701 & 1,713 & 1,785 & 1,633 & 1,324 & -65 \\
\hline Têxteis & 220 & 51 & 56 & 45 & 48 & 54 & 54 & 51 & 47 & 47 & -78 \\
\hline Fertilizantes & 898 & 94 & 136 & 217 & 241 & 184 & 156 & 138 & 118 & n.d. & $-87^{c}$ \\
\hline Charutos & 308 & 208 & 186 & 192 & 194 & 214 & 264 & 284 & 241 & 330 & +7 \\
\hline Pesca & 192 & 94 & 88 & 102 & 120 & 136 & 133 & 145 & 162 & n.d. & $-16^{c}$ \\
\hline Cítricos & 1,016 & 644 & 540 & 585 & 690 & 835 & 744 & 795 & 998 & 893 & -12 \\
\hline Arroz & 532 & 177 & 387 & 396 & 573 & 614 & 441 & 567 & 462 & n.d & $-13^{c}$ \\
\hline Leite de Vaca & 1.131 & 585 & 636 & 638 & 640 & 651 & 655 & 618 & 614 & 644 & -43 \\
\hline Ovos & 2,673 & 1,51 & 1,647 & 1,542 & 1,412 & 1,632 & 1,416 & 1,753 & 1,688 & 1,513 & -43 \\
\hline
\end{tabular}

a Bilhões de Kwh. ${ }^{\text {b }}$ BCC 2001 e ECLAC 2202b; 2,635 de acordo com ONE 2001 e 2,899 em Rodríguez Castellón 2001 e Triana 2002. ${ }^{\circ}$ 2000/1989 porque 2001 não está disponível.

Fontes: CCE 1991; ONE 1999, 2000, 2001; BCC 2000, 2001; ECLAC 2001a, 2002b; Pérez Villanueva 2001, Triana 2001.

1. Níquel. A produção de níquel diminuiu 43\% em 1989-1994, mas com um investimento de US\$350 milhões da Sherritt International Corporation, superou o pico anterior em 1996 e manteve-se em crescimento desde então. A produção em 2001 foi de 76.500 toneladas, 62\% acima do nível de 1989, mas os preços mundiais do níquel declinaram em $40 \%$ e o valor de exportação foi US\$210 milhões menor do que em 2000. Há três unidades industriais em operação: René Ramos Latour (antiga Nicaro americana), Pedro Soto Alba (antiga Moa americana) e Ernesto Che Guevara (construída com ajuda soviética); a unidade de Camariocas ainda não está pronta. Em 1989, a capacidade instalada das três plantas era respectivamente: $22.500,24.000$ e 30.000 , para um total de 76.500 toneladas. 
Porém, a produção de 1989 foi de apenas 47 mil toneladas, porque a Che Guevara estava apenas começando, consumia muita energia e precisava de modernização, assim como a Ramos Latour (Mesa-Lago, 2000). A produção em 2000 foi a seguinte: 10.787 toneladas em Ramos Latour (a capacidade de produção era menos da metade de 1989 devido a dificuldades para introduzir novas tecnologias), 29.520 toneladas em Soto Alba e 31.055 em Che Guevara, para um total de 71.360 toneladas. Portanto, a produção atual está abaixo da capacidade instalada de 1989, apesar dos investimentos da Sherritt. Em 2000, Che Guevara usou a metade do combustível que utilizou em 1990, mas ainda consumia 18 toneladas de óleo por tonelada de níquel produzida, em comparação com 12 a 15 toneladas em Soto Alba (BCC, 2001; Portal, 2001; Marquetti, 2002).

2. Petróleo. A extração de petróleo atingiu um pico de quase um milhão de toneladas em 1986, declinou em 44\% em 1987-1991, cresceu em 1992-95, ficou estagnada em 1996-97 e expandiu-se rapidamente em 1998-2001, para alcançar um recorde de 2,8 milhões de toneladas no último ano (outras estimativas falam em 2,6 a 2,9 milhões). A produção de 2001 foi quase quatro vezes a de 1989 e três vezes a de 1986. Esse desempenho impressionante foi conseqüência de US\$450 milhões em investimento externo, dois terços do investimento total nesse setor crucial (Triana, 2000). 42,3\% da necessidade total de energia de Cuba é satisfeita com a produção doméstica, principalmente de bagaço (25\%) e óleo cru (17\%); a contribuição do gás natural e da energia hidroelétrica é mínima (0,3\%). As importações cobrem $58,4 \%$ das necessidades, sendo $46 \%$ de derivados de petróleo e $12 \%$ de óleo cru. A contribuição da produção interna de óleo cru para o total das necessidades deste produto e derivativos foi de $22 \%$ em 1999, uma elevação em relação aos 11,6\% de 1987 (Mesa-Lago, 2000; Rodríguez Calderón, 2001). O aumento na produção doméstica reduziu a dependência energética do exterior pela metade do que era há uma década, mas ainda era de 67\% em 2001 (ECLAC, 2002b).

3. Açúcar. Até 1999, o açúcar era a principal fonte de receita de exportação, mas a situação mudou em 2000, quando o níquel o superou. A estreita relação entre açúcar e PIB foi mostrada por Triana em 2000, mas esse setor vital foi incapaz de recuperar o nível de 8 milhões de toneladas que apresentava nos anos oitenta: "A indústria açucareira passou por um estado depressivo e seu desempenho decide o ritmo e a dimensão do processo de recuperação econômica" (Marquetti, 2000, p.11). Depois de pequenos aumentos nas colheitas de 1999 (3,8 milhões de toneladas) e 2000 (4 milhões de toneladas), a produção declinou para 3,5 milhões de toneladas em 2001: a terceira mais baixa depois da Revolução (as piores foram em 1995 e 1998, cerca de 3,2 milhões de toneladas), 30\% abaixo da 
meta de 5 milhões de toneladas e 56\% abaixo do nível de 1989. Em termos per capita, o declínio foi de 0,76 toneladas em 1989 para 0,31 toneladas em 2001, a metade da produção per capita de 1943 (0,60 toneladas).

O Ministro do Açúcar, general Ulises del Toro, culpou o clima (uma seca) pelo fracasso, mas outros fatores foram responsáveis. A produção média anual (em milhões de toneladas) caiu constantemente nas últimas duas décadas: 7,8 em 1981-85, 7,6 em 1986-90, 5,2 em 1991-95, 3,9 em 1996-2000 e 3,5 em 2001 (Mesa-Lago, 2000 e Tabela 5). A área total plantada declinou em 22\% em 1990-99, de 1,76 para 1,38 milhões de hectares, enquanto a área irrigada diminuiu de $22 \%$ para $9 \%$ da área total plantada. A produção agrícola por hectare despencou de 60, em 1989 (59,4 no setor estatal e 62,8 no setor não-estatal), para 34,1 em 1999 (31,5 e 34,4 respectivamente). As ervas daninhas cobrem de $10 \%$ a $15 \%$ da área plantada e há uma grave escassez de herbicidas. Devido ao declínio da produção interna, bem como das importações, o uso de fertilizantes químicos diminuiu e parte foi substituída por fertilizantes naturais. Devido à escassez de combustível, a maior parte do transporte é feito por tração animal e isso, combinado com a falta de peças sobressalentes, reduziu o número de cortadores de cana em operação e a capacidade dos centros de limpeza de cana-de-açúcar (CCE, 1991; ONE, 1999, 2000, 2001; Orrio, 2001). Por fim, a produção industrial diminuiu constantemente depois da Revolução: de 12,5 em 1961-65 para 11,0 em 1981-85 e 10,9 em 19962000 (Mesa-Lago, 2000; ONE, 2001).

A safra de açúcar de 2002 foi de 3,6 milhões de toneladas, 78 mil (toneladas) a mais do que em 2001, mas a um custo muito alto. Em 1995-2000, investiram-se 980 milhões de pesos para modernizar a indústria açucareira, mas a ineficiência de muitas usinas (somente 106 estavam funcionando na colheita de 2002), os preços altos e a escassez de petróleo e os preços baixos do açúcar no mercado mundial tornaram a produção insustentável na metade das usinas. Foi então anunciado que 71 do total de 156 usinas seriam fechadas para economizar custos de energia e mão-de-obra e que as correspondentes terras plantadas com cana seriam usadas para outros produtos agrícolas. Calculou-se que cem a duzentos mil trabalhadores irão perder o emprego e que a capacidade da indústria açucareira será cortada em cerca de 40\% (Schweimler, 2002).

4. Manufatura. Para esta análise, selecionamos cinco produtos manufaturados que desempenharam um papel essencial no processo de industrialização de Cuba antes da crise, principalmente para consumo interno, mas também para exportação. Com exceção dos charutos, a produção encolheu drasticamente em 1983-1993 e cresceu a partir de então, mas a produção em 1999-2001 ficou abaixo do nível de 1989: -87\% em fertilizantes, $-78 \%$ em têxteis, $-65 \%$ em cimento e $-6 \%$ em eletricidade (mas houve um aumento de $7 \%$ em 
charutos). Vários fatores contribuíram para esse resultado negativo: escassez de combustível, falta de peças sobressalentes (a maioria das fábricas cubanas foi construída e equipada pela URSS e outros países do leste europeu, que não fornecem mais peças), dificuldades para adquirir os necessários inputs no exterior e ausência de demanda externa (exceto para charutos). De acordo com Marquetti (2000), o nível de descapitalização e obsolescência tecnológica em vários ramos industriais é de $30 \%$.

5. Pesca. A pesca foi um dos principais sucessos econômicos da Revolução, mas seus problemas começaram, de fato, antes da crise. O setor alcançou 244 mil toneladas em 1986, caiu para 192 mil toneladas em 1989, a crise reduziu para 88 mil toneladas em 1994 e houve uma lenta recuperação no período 1995-2000, atingindo 162.300 toneladas em 2000. Neste ano, a produção ficou $16 \%$ abaixo do nível de 1989 e 34\% abaixo do pico de 1986. Não há dados agregados disponíveis para 2001, mas a pesca de atum diminuiu $24 \%$, a de camarão e lagosta $9 \%$ e a de outras espécies $24 \%$. A indústria sofre com dívidas altas, má gestão financeira, falta de liquidez em pesos e dólares, pouca credibilidade junto aos credores, corrupção (o ministro foi demitido em março de 2000) e danos causados pelo furacão.

6. Agricultura. O setor agrícola não-açucareiro (tanto para consumo interno como para exportação) teve um mau desempenho e sua recuperação tem sido lenta e instável. Assim, em 2000-2001, a produção ficou abaixo do nível de 1989 nos seguintes alimentos básicos: $-43 \%$ de leite, $-48 \%$ de ovos, $-13 \%$ de arroz e $-12 \%$ de cítricas. Declínios semelhantes ocorreram com outras frutas e folhas de tabaco; a produção deste último atingiu um pico de 53.696 toneladas em 1981, caiu para 40.949 toneladas em 1989 e 16.890 toneladas em 1994, mas aumentou para 37.987 em 2000, embora ainda $29 \%$ abaixo do pico e $7 \%$ abaixo de 1989 . Ao contrário, a produção de verduras e legumes, tubérculos, milho e feijão aumentou mas, em termos per capita, ficou estagnada ou diminuiu (CCE, 1991; ONE, 1999, 2000, 2001; BCC, 2001; ECLAC, 2000a). A quantidade de cabeças de gado chegou a 6,8 milhões em 1967, mas caiu para 4,1 milhões em 2000; em cabeças per capita, a queda foi de 0,83 para 0,37. A dizimação do gado levou a uma queda de $47 \%$ na produção de carne e leite (Mesa-Lago, 2000; ONE, 1999, 2000, 2001). Em 2001, houve outra diminuição na produção de frango e ovos e o racionamento destes passou de doze para seis ovos mensais por pessoa; um ovo custa três pesos no mercado negro e o produto desapareceu das lojas onde se compra em dólar, exceto para diplomatas. Uma causa importante para a queda dos produtos diários foi a falta de ração para gado e frangos, cuja importação caiu 52\% em 1989-2000 (Espinosa, 2002). O furacão Michelle também causou uma perda de US\$317 milhões na agricultura e afetou as plantações de cítricas, provocando uma queda 
em sua produção.

A terceira reforma agrária realizada em 1993-94 não conseguiu resolver problemas da agricultura como a ineficiência e a falta de incentivos. As novas Unidades Básicas de Produção Cooperativa (UBPC) dependem muito do Estado que, na prática, dirige a produção e compra ela quase toda a preços estabelecidos abaixo do preço de mercado, criando assim sérios desincentivos. Em conseqüência, em 1997, a participação da UBPC nas terras cultivadas foi de 57,6\%, mas nas vendas totais nos mercados agrícolas livres foi de 3,6\%; ao contrário, a participação do setor privado foi respectivamente de 16,9\% e 72,7\%. Em 1995-96, 94\% das UBPCs sofreram perdas e precisaram de subsídios estatais; em 1999-2000, essa proporção foi reduzida para $37 \%$, mas ainda era muito alta. Outro problema é a crescente concentração em tamanho das UBPCs que as torna mais difíceis de administrar. As UBPC operam 74\% das plantações de cana-de-açúcar, o que explica, em larga medida, o fracasso desse setor. Por fim, o total de terra agrícola cultivada diminuiu em 13\% em 1990-97 (ECLAC, 2000a; Novoa, 2001).

\section{Indicadores sociais e trabalhistas}

1. Desemprego. A Tabela 6 seleciona quatro indicadores-chaves sociais e trabalhistas. A taxa de desemprego aberto foi reduzida de 7,9\% em 1989/1995 para 5,5\% em 2000 e 4,5\% em 2001, um declínio de 43\% (em algumas províncias orientais, a taxa foi muito mais alta, por exemplo, 14\% em Granma). O governo planeja reduzir a taxa para 3,9\% em 2002, apesar da anunciada demissão de cem a duzentos mil trabalhadores da indústria açucareira (de acordo com as autoridades, a subsistência desses trabalhadores e de suas famílias será preservada). A “taxa de desemprego equivalente" (desemprego aberto mais trabalhadores postos a disposição que recebem compensação), estimada pela $\operatorname{ECLAC~(1998,~2000a),~}$ atingiu um pico de 35,2\% em 1993, mas diminuiu para 25,1\% em 1998 (último ano com dados disponíveis). A questão é saber como essas duas coisas foram conseguidas se em 1995, entre quinhentos e oitocentos mil trabalhadores do setor estatal estavam à disposição ou seriam demitidos. O pequeno setor privado está estagnado, sob regulamentos e impostos cada vez mais apertados. 
Tabela 6

Indicadores sociais e trabalhistas cubanos: 1989-2001

\begin{tabular}{||l||c|c||c|c||c|c||c||c||c||c||c||}
\hline \multicolumn{1}{|l|}{ Indicadores } & $\mathbf{1 9 8 9}$ & $\mathbf{1 9 9 3}$ & $\mathbf{1 9 9 4}$ & $\mathbf{1 9 9 5}$ & $\mathbf{1 9 9 6}$ & $\mathbf{1 9 9 7}$ & $\mathbf{1 9 9 8}$ & $\mathbf{1 9 9 9}$ & $\mathbf{2 0 0 0}$ & $\mathbf{2 0 0 1}$ & $\begin{array}{c}\text { \% 2001- } \\
\mathbf{1 9 8 9}\end{array}$ \\
\hline $\begin{array}{l}\text { Desemprego } \\
\text { aberto (\% } \\
\text { EAP) }\end{array}$ & 7.9 & 6.2 & 6.7 & 7.9 & 7.6 & 7.0 & 6.6 & 6.0 & 5.5 & 4.5 & 43 \\
\hline $\begin{array}{l}\text { Gastos com } \\
\text { seguridade } \\
\text { social(\% GDP) }\end{array}$ & 10.1 & 15.8 & 13.2 & 12.3 & 12.1 & 12.2 & 12.4 & 13.0 & 13.3 & 13.7 & +35 \\
\hline \hline $\begin{array}{l}\text { Mortalidade } \\
\text { infantil (por } \\
\text { 1000) }\end{array}$ & 11.1 & 9.4 & 9.9 & 9.4 & 9.0 & 7.2 & 7.1 & 6.4 & 7.2 & 6.2 & 44 \\
\hline $\begin{array}{l}\text { Matrículas na } \\
\text { universidade } \\
\text { (milhares) }\end{array}$ & 242 & 166 & 141 & 122 & 112 & 105 & 102 & 107 & 107 & 116 & 52 \\
\hline
\end{tabular}

Fontes: Mortalidade infantil e matrículas na universidade de CCE 1991; ONE 1999, 2000, 2001. Desemprego de ECLAC 2000a, 2000b, ONE 2001. A seguridade social inclui saúde, pensões e assistência social, de Mesa-Lago 2002 e ONE, 2001.

As medidas tomadas em 1996-2001 contra o auto-emprego e outras atividades no setor privado foram: (a) aumento de $300 \%$ nas licenças e $650 \%$ nas taxas dos auto-empregados; (b) impostos de US\$ 850 mensais para pequenos restaurantes (paladares) e US\$250 para um quarto alugado a turistas (as violações de aluguel acarretam multas de US\$ 1.000 a US\$ 1.800 por hóspede); (c) suspensão de novas licenças para paladares; (d) proibição aos táxis privados de transportar turistas; (e) fechamento de galerias privadas independentes: somente as galerias estatais podem vender obras de arte; e (f) uma taxa de 300 pesos para os "vídeobares" e 800 pesos para o aluguel de roupas (Bauzá, 2001; Cawthorne, 2001; Henken, 2002). Essas medidas levaram à diminuição do número de trabalhadores auto-empregados registrados, de 208.500 no final de 1995 para 156.600 em 1999 (ECLAC, 1998; ONE, 2000). O ministro da Economia J osé Luis Rodríguez declarou: “Não é nossa política eliminar o auto-emprego [...] Mas não o estimulamos porque não acreditamos que seja a maneira de tirar nosso país de suas dificuldades econômicas" (citado por Cawthorne, 2001). Um projeto de lei que circulou em 1995, que permitia aos cubanos possuir e operar pequenos negócios, foi para o limbo e não foi discutido nos últimos três anos. 
OPINIÃO PÚBLICA, Campinas, Vol. IX, no 1, 2003, pp. 190-223

2. Salários reais. A Tabela 7 apresenta dois índices de salários reais em 1989-1999, convertidos para o ano de 1989 como base: Togores indica um declínio de $42 \%$, enquanto ECLAC exibe números mais altos e uma queda de $39 \%$. O poder de compra dos salários diminuiu ainda mais em 2002 porque os preços nas lojas que vendem em dólar saltou $30 \%$ em junho e os preços agrícolas aumentaram de $20 \%$ a $66 \%$ na primeira metade de 2002 , em comparação com o mesmo período de 2001. A falta de conexão entre salários e preços reais é um obstáculo para o aumento do consumo da população e um desincentivo à produtividade, que diminuiu de 5,4\% em 1999 para 4,6\% em 2000 e 2,3\% em 2001; nos últimos dois anos, ela foi menor do que o crescimento do PIB (Triana, 2000, 2002). Uma pesquisa feita em 1999 pelo Instituto Nacional para la Salud de los Trabajadores detectou um aumento de 41\% na insatisfação dos trabalhadores (Garve, 2001).

Tabela 7

Estimativas de salários reais e índices de salário real em Cuba: 1989-1999

\begin{tabular}{|c|c|c|c|c|c|c|c|c|}
\hline Fonte & 1989 & 1993 & 1994 & 1995 & 1996 & 1997 & 1998 & 1999 \\
\hline \multicolumn{9}{|l|}{ Togores } \\
\hline $\begin{array}{l}\text { Salário médio } \\
\text { nominal }\end{array}$ & 189 & 184 & 186 & 195 & 207 & 206 & 206 & 221 \\
\hline $\begin{array}{l}\text { Índice de preços ao } \\
\text { consumidor }\end{array}$ & 1.443 & 6.578 & 5.575 & 2.940 & 2.883 & 2.904 & 2.983 & 2.896 \\
\hline Salário real & 130.98 & 27.97 & 33.36 & 66.32 & 73.34 & $70.94^{a}$ & $69.05^{a}$ & 76.31 \\
\hline $\begin{array}{l}\text { Índice de salário real } \\
(1989=100)\end{array}$ & 100.00 & 21.35 & 25.47 & 50.63 & 55.99 & $54.16^{a}$ & $52.72^{a}$ & 58.26 \\
\hline \multicolumn{9}{|l|}{ ECLAC } \\
\hline $\begin{array}{l}\text { Índice de preços ao } \\
\text { consumidor }\end{array}$ & 0.962 & 1.245 & 1.645 & 1.862 & 1.898 & 1.896 & 1.922 & 1.866 \\
\hline $\begin{array}{l}\text { Índice do salário } \\
\text { nominal }(1990=100)\end{array}$ & 100.5 & 97.3 & 98.9 & 103.7 & 108.0 & 110.2 & 110.2 & 118.2 \\
\hline $\begin{array}{l}\text { Índice do salário real } \\
(1990=100)\end{array}$ & 104.5 & 78.1 & 60.1 & 55.7 & 56.9 & 58.1 & 57.3 & 63.3 \\
\hline $\begin{array}{l}\text { Índice do salário real } \\
(1989=100)\end{array}$ & 100.0 & 74.7 & 57.5 & 53.3 & 54.4 & 55.6 & 54.8 & 60.6 \\
\hline
\end{tabular}

a Togores usa salários nominais mais altos do que os de fato: 214 em 1997 (em vez de 206) e 217 em 1998 (em vez de 206); em conseqüência, os salários reais são mais altos: 73.68 e 72.75 respectivamente; o autor recalculou o salário real e o índice baseado em dados reais.

${ }^{\mathrm{b}}$ Calculado pelo autor comparando os índices de salário real e nominal da ECLAC.

Fontes: Salário médio nominal de CCE 1991, ONE 1999 e 2000. Togores 1999. ECLAC 2000a. O ano de 1999 são estimativas do autor baseadas na taxa oficial de deflação de $-2.9 \%$. 
3. Seguridade social. O custo da seguridade social (combinação de pensões, saúde e assistência social) vem subindo em conseqüência de vários fatores: cobertura praticamente universal, idades muito baixas de aposentadoria, a maturidade do programa de pensões e o envelhecimento da população (estima-se que, em 2025, Cuba terá a população mais velha da região e haverá apenas duas pessoas em idade produtiva para uma pessoa em idade de aposentar-se). A Tabela 6 mostra que os gastos com seguridade social enquanto porcentagem do PIB chegaram a 15,8\% em 1993, porque o PIB decresceu em 35\%, mas os gastos com a previdência continuaram aumentando. À medida que o PIB cresceu, o peso proporcional da seguridade social declinou e estabilizou-se em cerca de $12 \%$ em 1995-98 mas, uma vez que esses gastos expandiram-se mais depressa do que o crescimento da economia, esse peso aumentou para 14\% em 2001 e deverá continuar crescendo no futuro. Ademais, há um déficit em expansão no plano de aposentadorias que é coberto pelo Estado (6,4\% do PIB em 2001). A pensão média real declinou 42\% em 1989-1998 e a pensão média mensal de 104 pesos em 2001 era equivalente a US $\$ 4,70$. O sistema de racionamento só proporciona rações de alimentos para um terço do mês (por cerca de 25 pesos): o resto da comida e outros bens de consumo essenciais devem ser comprados com US\$ 4,70 nas lojas que vendem a dólar e nos mercados agrícolas, onde os preços são muito altos (Mesa-Lago, 2002). O governo está examinando uma reforma considerável do plano de pensões que poderá aumentar a idade da aposentadoria, implementar contribuições de trabalhadores e incorporar o crescente setor privado (Gutiérrez e Peñate, 2000).

4. Saúde. A taxa de mortalidade infantil continuou a diminuir: caiu de 11,1 (por 1000 crianças nascidas vivas) em 1989 para 6,4 em 1999, aumentou para 7,2 em 2000 e diminuiu para 6,2 em 2001, para um declínio de $44 \%$ no período (Tabela 6). Essa taxa foi a mais baixa da América Latina e o Caribe (BCC 2000). Por outro lado, as taxas de incidência para onze moléstias contagiosas em 1994-2000 mostraram aumentos em sete delas (respiratória aguda, catapora, hepatite, escarlatina, sífilis, tuberculose e febre tifóide) e continuação da ausência de notificação em cinco (difteria, malária, sarampo, pólio e tétano) (ONE 2001; MINSAP, 2000, 2001). Os dados sobre nutrição são extremamente difíceis de obter, mas o Programa de Desenvolvimento das Nações Unidas mostra as seguintes mudanças em 1970-1997 no consumo diário per capita: calorias -6\%, proteínas $23,9 \%$ e gorduras $-27,7 \%$ (PNUD, 2000). O número de médicos aumentou quase duas vezes em 1989-2000, Cuba apresenta a maior proporção de médicos da região: 58,8 para 10.000 habitantes (MINASP, 2001; ECLAC, 2002a). Na verdade, há um excedente desses profissionais: "Estamos mandando milhares de médicos de graça para oferecer seus serviços [...] na América Latina, no Caribe e na África. Isso 
é possível graças aos nossos abundantes recursos humanos" (Castro, 2000). Milhares de médicos trabalham como taxistas, garçons em instalações turísticas e outras ocupações, onde podem ganhar várias vezes mais o salário pago em sua profissão.

5. Educação. O número de matrículas nas universidades diminuiu de forma constante em 1989-2000, com um pequeno aumento em 2001, para uma queda no período de $52 \%$ (Tabela 6). A porcentagem da população em idade de freqüentar a educação superior caiu de $21 \%$ em 1989-1990 para 12\% em 1998-1999. Em 199394, formaram-se 31.105 alunos nas universidades; esse número caiu para 10.706 em 1998-99 (ONE, 2001; Orrio, 2001; ECLAC, 2002a). As duas principais razões para esse declínio foram a falta de incentivo para os formados, que não conseguem achar emprego no setor estatal e são proibidos de praticar suas profissões por conta própria, e a fixação pelo governo de cotas reduzidas de matrícula nas universidades.

6. Distribuição. Uma pesquisa sobre as condições econômicas dos lares na cidade de Havana em março de 2000 revelou o seguinte: (a) a renda média per capita era de 198 pesos (US\$ 9,90 pela taxa de câmbio não oficial); (b) 53\% dos lares tinham uma renda per capita entre 50 e 150 pesos (US\$2,50 a US\$7,50) e $14 \%$, menos de 50 pesos; (c) $78 \%$ dos gastos com alimentação eram feitos em mercados agrícolas e privados; e (d) $77 \%$ declararam que sua renda era insuficiente para cobrir as despesas (Oficina Territorial de Estadísticas de la Ciudad de La Habana, Encuesta sobre la situación económica de los hogares, citado por Pérez Villanueva, 2001). Em trabalho anterior, registrei que as desigualdades haviam se expandido significativamente nos anos noventa (Mesa-Lago, 1998). O racionamento estendeu-se para todos os bens de consumo, mas deixou de ser um igualador significativo porque as rações mensais cobrem menos de duas semanas das necessidades alimentares mínimas e o resto precisa ser comprado em lojas estatais dolarizadas ou nos mercados agrícola e negro, a preços muito altos que só podem ser pagos por quem ganha ou recebe moeda forte de fora. Por fim, há uma significativa concentração nas contas bancárias: $12 \%$ dessas contas abrigam $80 \%$ do total de depósitos (5,3 bilhões de pesos) e novas contas que rendem até $7 \%$ de juros irão aumentar essa concentração (Triana, 2000).

7. Habitação. "A habitação é reconhecida como o problema social mais grave que afeta a nação [...] as necessidades acumuladas [déficit habitacional] são substancialmente maiores do que a construção de novas moradias devido, entre outros motivos, à deterioração do estoque existente" (Triana, 2000, p. 10). Em Havana, a situação é particularmente difícil: em 1999, de 575.795 unidades, 
somente $57 \%$ estavam em "boas condições" e os outros $43 \%$ estavam "regulares" ou em "más condições". A situação era pior em alguns bairros pobres (por exemplo, Havana Velha), onde $75 \%$ das moradias foram classificadas como regulares ou ruins. Na pesquisa citada acima, 59,3\% dos lares registraram problemas de construção e embora 98,3\% tivessem água encanada, somente 49,8\% recebiam água diariamente (Pérez Villanueva, 2001). O furacão Michelle danificou 166.515 casas, das quais pelo menos 12.759 foram totalmente destruídas; no entanto, construíram-se apenas 34 mil moradias em 2001, aumentando assim o déficit (Triana, 2002).

\section{Metas para 2001 e adiante, e debate sobre a estratégia futura}

Esta seção avalia o cumprimento de metas estabelecidas no plano qüinqüenal de 1998-2002, bem como o ano de 2001 e as perspectivas para 2002; além disso, resume as opiniões dos economistas cubanos sobre os problemas atuais e suas sugestões para o futuro.

1998-2002. O V Congresso do Partido Comunista cubano, realizado em outubro de 1997, estabeleceu metas muito ambiciosas para 1998-2002 (MesaLago, 1998): nenhuma delas foi alcançada até 2001 e, com a possível exceção do turismo, não serão cumpridas em 2002: (1) crescimento do PIB a uma taxa anual de $4 \%$ a $6 \%$ (na verdade, uma média de 4\% em 1998-2001); (2) aumento da produção de açúcar para 7 milhões de toneladas (na verdade, ficou na média de 3,6 milhões em 1998-2002); (3) aumento da produção de níquel para cem mil toneladas (a produção em 2001 foi de 76.500 toneladas, perto da capacidade instalada); (4) aumento da produção de folhas de tabaco para 50 mil toneladas (a produção em 2000 foi de 37.987 toneladas); (5) dois milhões de turistas e uma receita bruta de US\$2,6 bilhões (foram 1,77 milhões de turistas e uma receita de US\$ 1,84 bilhões em 2001); (6) as necessidades de petróleo satisfeitas com o aumento da produção interna e economias (a contribuição interna para o total do abastecimento de petróleo foi de 33\% em 2001); e (7) construção de 50 mil habitações anuais (foram construídas 41 mil moradias anuais em 1998-2001). O VI Congresso do PCC está marcado para 2002 e será interessante ver se o partido avaliará as metas estabelecidas pelo V Congresso.

2001. Das catorze metas econômicas estabelecidas para o ano de 2001, somente duas foram cumpridas (níquel e charutos). Vejamos: (1) crescimento de $5 \%$ do PIB (foi de 2,5\%); (2) aumento de 14\% nos investimentos (foi de 4,4\%); (3) déficit fiscal de $2,2 \%$ do PIB (foi de 2,5\%); (4) dois milhões de turistas e US\$2,2 bilhões de receita bruta, para um aumento de 15\% (foram 1,77 milhões de turistas 
e US\$ 1,84 bilhões em receita bruta - uma diminuição de 10\%); (5) quatro milhões de toneladas de açúcar (foram 3,5 milhões de toneladas); (6) expansão de 5,7\% na produção de níquel, para atingir 75 mil toneladas (foram 76.500 toneladas), mas o declínio dos preços internacionais levou a um declínio do valor da exportação; (7) 3,4 milhões de toneladas de petróleo, num salto de $26 \%$ (foram 2,8 milhões de toneladas); (8) aumento de $36 \%$ na produção de charutos (cumprido); (9) crescimento de $7,4 \%$ da produção industrial (foi de 0,5\%); (10) impulso para a produção agrícola não-açucareira (houve uma diminuição de 1,7\%; ECLAC, 2002b); (11) aumento de $20 \%$ nas exportações (houve um declínio de 0,8\%); (12) aumento de $4 \%$ nas importações (houve um declínio de 1\%); (13) corte de 4,5\% no déficit no comércio exterior de bens (houve corte de 1\%); e (14) implementação plena do "sistema de perfeição empresarial" (somente trezentas das três mil empresas estavam com sistema em operação em 2001) ${ }^{7}$. Não foram estabelecidas metas de inflação, liquidez monetária, outras linhas de produção e na área social (metas de Rodríguez, 2000; BCC, 2001; Triana, 2001; dados anteriores de ONE, 1999, 2000, 2001; BCC, 2002; Frank, 2001; ECLAC, 2002b).

2002. O Plano Econômico e Social para 2002 ainda não foi publicado e, portanto, não há metas oficiais concretas, embora algumas delas tenham sido reveladas em discursos públicos. As perspectivas em dez setores cruciais são brevemente discutidas em seguida. (1) Macroeconomia: o crescimento do PIB foi estabelecido em 3\%, mas é considerado otimista por alguns economistas cubanos; o déficit orçamentário está planejado para aumentar para 2,9\% do PIB; (2) Remessas do exterior: podem estagnar ou declinar, exceto se houver uma forte recuperação econômica dos Estados Unidos, o que não era o caso até o final de julho de 2002; (3) Turismo: o número de turistas diminuiu 37\% em janeiro-fevereiro de 2002 (em relação aos mesmos meses de 2001) e a taxa de ocupação caiu 20$30 \%$ nos hotéis Gran Caribe (a principal cadeia); (4) Níquel: de acordo com Carlos Lage, não há expectativa de que os preços internacionais aumentem na primeira metade do ano e o governo está tentando evitar o fechamento de algumas das unidades de produção; (5) Açúcar: quatro milhões de toneladas eram a meta, mas foram produzidas 3,6 milhões, que geraram US\$ 120 milhões em exportações, menos do que em 2001 devido aos preços mais baixos do açúcar (45\% das usinas serão fechadas devido à pouca eficiência); (6) Petróleo: a meta são quatro milhões de toneladas, um aumento de 38\% na produção, mas em 2001, a principal empresa petrolífera (EPEP-C) interrompeu a produção pela primeira vez em oito

\footnotetext{
${ }^{7} \mathrm{Na}$ metade de 2002, 321 empresas estavam funcionando conforme o sistema, depois de quatro anos do início do processo. Foram detectados problemas sérios até mesmo entre as empresas "aperfeiçoadas": falta de controle orçamentário (o orçamento não é usado como ferramenta gerencial), não utilização de dados contábeis para controlar o cumprimento das metas do plano (outros critérios são usados para medir a produção), falta de regras para avaliações trimestrais e declínio das vendas (Lee, 2002b).
} 
anos devido a maus resultados; enquanto se espera que outra empresa (Petróleo de Occidente) lidere a indústria, a suspensão das entregas venezuelanas provocou blecautes, suspensão de produção e redução do número de ônibus em operação; (7) Pesca: essa indústria está com graves problemas financeiros; sofre com dívidas altas, falta de liquidez (em pesos e dólares), fraca credibilidade entre os credores e corrupção, bem como com os danos causados aos navios pelo furacão; será muito difícil reverter o declínio da produção em 2001; (8) Indústria básica: em fevereiro, ainda estava reparando os danos causados pelo furacão; além disso, a produtividade e a qualidade são baixas, o que reduz a competitividade nas exportações; (9) Habitação: planejam-se construir apenas vinte mil casas, catorze mil a menos do que em 2001; e (10) Saúde empresarial: de acordo com o presidente do Banco Central, a partir de setembro de 2001, o sistema bancário estatal deixaria de dar crédito a empresas que estivessem atrasadas nos pagamentos e, em janeiro de 2002, todos os serviços bancários para essas empresas seriam suspensos se não corrigissem a situação; no final de 2001, o Banco congelou os fundos de setenta entidades estatais e esperavam-se falências em 2002 (baseado em De J esús, 2002; Ferradaz, 2002; Granma, 3 de junho de 2002; Jiménez, 2002; Lage, 2002; Lee, 2002a; MINFP 2001; “Ministro..." 2002; Núñez, 2002; Rodríguez, 2001; Triana, 2002).

\section{Análise dos estudiosos cubanos dos problemas atuais e sugestões para o futuro}

Na primeira metade dos anos noventa, houve um acalorado debate em Cuba sobre alternativas para a reforma econômica, que foi abruptamente suspenso na metade de 1996. Em 2000-2002, houve um modesto renascimento da análise de problemas econômicos e propostas de reformas. As limitações de tempo e espaço impedem um exame aprofundado de todas as posições existentes; desse modo, esta seção resume as opiniões de cinco economistas cubanos: Carranza, 2001; González, 2001; Marquetti, 2000; Monreal, 2001 e Triana, 2000. Todos eles elogiam o progresso alcançado, alguns rejeitam explicitamente o neoliberalismo e praticamente todos expressam a necessidade de trabalhar dentro de uma moldura socialista. Embora existam diferenças lógicas entre eles, sua posição na identificação dos problemas atuais e no estabelecimento de diretrizes para soluções é bastante similar. Tentei traduzir fielmente e resumir as opiniões desses estudiosos, mas sou inteiramente responsável por qualquer erro de interpretação de suas concepções. 
1. Problemas. (1) o progresso realizado não tem suporte sólido para garantir a sustentabilidade da recuperação e foi incapaz de reconstruir as bases internas da acumulação de capital (Marquetti); (2) o ajuste macroeconômico ainda é insuficiente e continua a gerar tensões econômicas e sociais, o processo de mudança gera uma tensão interna entre objetivos econômicos e efeitos sociais (Carranza, González); (3) a URSS e outros países socialistas contribuíram para um alto nível de acumulação de capital antes dos anos noventa, mas não há possibilidade de voltar àquelas condições favoráveis, os novos investimentos foram insuficientes e não desempenharam o papel essencial exigido para o crescimento de longo prazo, é impossível restringir ainda mais o consumo, pois já está muito deprimido, e a única saída é aumentar a eficiência interna e a competitividade das empresas (Marquetti); (4) o turismo, os investimentos externos, as remessas do exterior e algumas exportações ajudaram na recuperação econômica dos anos noventa, mas seus efeitos multiplicadores são insuficientes para manter um crescimento dinâmico e reduzir a dependência externa, em 2001 a economia ainda não se recuperou completamente e está abaixo do nível de 1989 (Carranza, Marquetti); (5) a indústria açucareira está num estado depressivo que causa um impacto adverso na recuperação econômica: a queda da produção de açúcar prejudicou a manufatura e a economia em geral e reduziu o acesso ao crédito internacional, o declínio da participação do açúcar no total das exportações não foi resultado do crescimento de outras exportações (Marquetti, Monreal); (6) a maioria (83\%) das exportações cubanas (açúcar, níquel, tabaco e peixe) é composta por produtos primários tradicionais típicos de países subdesenvolvidos, enquanto apenas uma minoria minúscula $(7 \%)$ é composta por produtos manufaturados ou semi-manufaturados. Estes últimos desempenharam, portanto, um papel muito pequeno na geração de exportações, resultando numa dependência excessiva de atividades com baixo nível de processamento dos recursos naturais e na estagnação das exportações com alto valor agregado e complexidade tecnológica (Monreal, Carranza); (7) os serviços turísticos não envolvem avanço industrial, são típicos de países subdesenvolvidos, não são um indicador de progresso no sentido de modos mais altos de inserção internacional e não conduzem necessariamente ao desenvolvimento (Monreal); (8) a biotecnologia não fez inserções significativas no mercado internacional; (9) a dependência excessiva e crescente da importação de alimentos essenciais (bem como de combustível) restringe a importação de bens de capital e intermediários, cruciais para o crescimento econômico (Carranza); (10) há um componente importado excessivo nas atividades que geram moeda forte, como turismo (González); (11) a sobrevalorização do peso na taxa de câmbio oficial provoca efeitos negativos em termos de incentivos para a exportação (Triana); (12) o crescimento econômico não reduziu o déficit da balança de pagamentos, um obstáculo para mais crescimento, e há acesso escasso ao crédito externo, que é de 
curto prazo e muito caro, tornando difícil pagá-lo (Carranza, Marquetti); (13) a moeda dupla em circulação e a dupla taxa de câmbio são problemas que precisam ser corrigidos (González); (14) a liquidez monetária aumentou significativamente em 2000, 79 meses depois do início do programa para combatê-la (desmonetización) há uma eficácia decrescente das ferramentas originais usadas para extrair dinheiro da circulação porque a maioria da população tem menos dinheiro para comprar bens caros nos mercados livres (Carranza); (15) os preços não declinaram em seis anos nos mercados agrícolas, alimentando assim a inflação e afetando o consumo da população (Carranza); (16) há uma desconexão entre salários (amarrados em larga medida a um peso sobrevalorizado no câmbio oficial) e preços de bens nos mercados livres (mais conectados à taxa de câmbio nãooficial), provocando assim efeitos adversos: distorções na produção agrícola devido à renda diferencial entre setores com preços controlados e não-controlados, estagnação relativa nos mercados livres fora da agricultura, obstáculos para restabelecer o trabalho como fonte fundamental da renda, desincentivos à produtividade dos trabalhadores e camponeses e obstáculos à melhoria do consumo da população (Carranza, Triana); (17) o modelo convencional de planejamento físico centralizado não é viável, mas não há consenso com respeito às várias propostas sobre o tipo de planejamento a seguir e também não há uma estratégia explicitamente definida de desenvolvimento, aspectos essenciais que requerem discussão (González, Carranza); (18) o sistema de aperfeiçoamento das empresas é incipiente e lento, há na verdade um surto de "verticalismo" e uma tendência no sentido da concentração empresarial, e o processo gerará superávit de mão-de-obra que será difícil de empregar em outro lugar (Carranza, González, Triana); e (19) os salários reais diminuíram e há desemprego disfarçado, renda estratificada e concentração significativa de depósitos bancários numa minoria da população (Triana, Carranza).

2. Sugestões de mudanças. A modificação parcial da estrutura econômica efetuada nos anos noventa foi incapaz de transformá-la no grau necessário para promover o desenvolvimento dentro do atual contexto internacional. A economia não pode crescer, como antes de 1990, tendo por base um modelo de acumulação extensiva e baixa eficiência, viável então somente porque havia apoio econômico da URSS e dos países socialistas. É inevitável, portanto, promover um debate rigoroso sobre as alternativas para enfrentar os efeitos da crise e acelerar sua solução por meio de uma estratégia mais lógica e viável (Carranza). Neste contexto, uma idéia propagada foi que a desaceleração de 1997-98 era um indicador de que a recuperação estava apoiada em fatores residuais, tornando assim difícil retornar a médio prazo ao nível anterior à crise. Outra opinião é que a desaceleração foi resultado da "paralisia relativa" da reforma econômica (Marquetti). A superação da 
crise atual exige um modelo de acumulação intensiva e maior eficiência, e isso só é possível com uma "reestruturação fundamental da economia e o término da reforma econômica com coerência adequada. A primeira década do século XXI é o momento para encarar esse desafio" (Carranza, Monreal).

As propostas específicas são poucas e sucintas: (1) a nova estratégia de desenvolvimento deve basear-se em setores que usam intensivamente mão-de-obra especializada em atividades de complexidade tecnológica crescente, o que aumentaria os incentivos aos trabalhadores e resolveria a contradição existente entre expectativas geradas pela especialização e remuneração (Carranza); (2) o principal potencial está no mercado interno, mediante um aumento de seu nível de competitividade, os ministérios deveriam exercer funções reguladoras, em vez de fiscalizadoras, os preços precisam ser reformados (Marquetti); (3) a estrutura das exportações deveria ser radicalmente transformada, aumentando a participação de produtos manufaturados, bem como de serviços equivalentes a manufaturas em termos de valor agregado, a utilização de conhecimento e complexidade tecnológica, promovendo assim um processo de reindustrialização, mas orientado para as exportações, em vez de voltado para o mercado interno como no passado; os modos de inserir a economia cubana no mercado mundial devem, portanto, ser redefinidos (Monreal); (4) as relações de propriedade e as instituições econômicas deveriam ser transformadas, formas diferentes de propriedade deveriam trabalhar juntas e a propriedade estatal ser dinamizada por meio de mais competição (González, Carranza); e (5) os mercados deveriam ser de compradores, em vez de vendedores, a fim de promover a competição e assim reduzir os preços e melhorar a qualidade; deve haver mais descentralização na administração, a economia interna deve adaptar-se ao ajuste externo e avançar progressivamente no sentido da convertibilidade do peso (González).

\section{Conclusões}

O crescimento do PIB em Cuba caiu de 6\% em 1999-2000 para 3\% em 2001 e, no último ano, o PIB per capita estava ainda 23\% abaixo do nível de 1989. Após três anos de deflação declarada oficialmente, em 2001, a liquidez monetária aumentou $16,4 \%$. O déficit fiscal aumentou de $2,4 \%$ para $2,5 \%$. O número de turistas estagnou e a produção de açúcar diminuiu 13\%, menos da metade do nível das colheitas nos anos oitenta. A produção de petróleo e níquel continuou a subir e atingiu recordes, mas a forte queda dos preços mundiais do níquel levou a uma redução de seu valor de exportação. A produção de produtos industriais e agrícolas essenciais (cimento, têxteis, eletricidade, ovos, peixes, cítricas) declinou ou estagnou, aumentando somente a de charutos; em 2000-2001, a produção de dez entre treze produtos fundamentais ainda estava abaixo do nível de 1989 . As 
exportações diminuíram 0,8\% (devido à queda em quantidade e valor do açúcar, bem como ao forte declínio dos preços do níquel), enquanto as importações declinaram 1\% (ainda assim, US\$ 3,1 bilhões). O déficit comercial foi parcialmente compensado com os ganhos com turismo, mas eles diminuíram $5 \%$ e o déficit em conta corrente aumentou em 10\%; as remessas do exterior permaneceram estagnadas ou declinaram levemente. Cuba teve de apelar para empréstimos de curto prazo mais caros e escassos para cobrir a diferença. A Venezuela (principal parceiro comercial agora) suspendeu as entregas de petróleo a preços subsidiados porque Cuba está com vários meses de atraso nos pagamentos. A dívida externa em moeda forte foi levemente reduzida de US\$11 para US\$10,9 bilhões, mas o investimento externo direto caiu $91 \%$. O desemprego aberto continuou a cair, mas não há relatórios sobre subemprego. Os salários nominais aumentaram um pouco, ao mesmo tempo que aumentos significativos em lojas dolarizadas e mercados agrícolas, combinados com a desvalorização do peso, levaram provavelmente a um declínio do poder de compra. Os gastos com a seguridade social saltaram para $14 \%$ do PIB, o índice mais alto da América Latina, e continuarão a crescer à medida que a população cubana envelhece rapidamente, para tornar-se a mais velha da região. A mortalidade infantil continuou seu declínio e ficou $44 \%$ abaixo do nível de 1989 , mas outros indicadores de saúde mostraram deterioração, tais como a incidência de enfermidades. As matrículas nas universidades começaram uma modesta recuperação da dramática queda dos anos noventa, mas em 2001 ainda estavam $52 \%$ abaixo do nível de 1989. O déficit habitacional aumentou com os danos causados pelo furacão e com o número consideravelmente menor de moradias construídas. A grande maioria das metas estabelecidas pelo $\mathrm{V}$ Congresso do PCC para 1998-2002 não foi cumprida e de catorze metas estabelecidas para 2001, doze também não foram. As perspectivas para 2002 parecem ser piores do que o desempenho em 2001. Houve um renascimento modesto da análise dos problemas econômicos por economistas cubanos, com um razoável grau de consenso, mas eles oferecem poucas recomendações concretas para melhorar a situação do país.

Para promover um crescimento econômico mais forte é essencial que se façam as seguintes mudanças: abrir mais a economia; facilitar a expansão do setor privado; transformar as UBPC em verdadeiras cooperativas, autônomas e com mais incentivos para aumentar a produção e a lucratividade; permitir que os formados pelas universidades pratiquem suas profissões por conta própria e autorizar os cidadãos cubanos e grupos de trabalhadores a administrar negócios pequenos e médios, criando assim empregos suficientes no setor não-estatal a fim de permitir a demissão de trabalhadores desnecessários do setor estatal; completar a reforma bancária e implementar uma reforma de preços abrangente; criar um mercado de capitais interno; permitir que empresas estrangeiras e joint-ventures contratem, promovam e paguem seus empregados diretamente; estabelecer um peso 
realmente conversível; introduzir um imposto de renda progressivo e contribuições dos trabalhadores à previdência social e reformar o sistema de pensões; e criar uma rede de segurança social para proteger os grupos mais vulneráveis da população. 


\section{BIBLIOGRAFIA}

"BALANCE DEL MINCEX" (Relatório do Vice-Ministro Eduardo Escandelli). 2002. Granma, 25 de março.

BANCO CENTRAL DE CUBA (BCC). 2000. Informe Económico 1999. Havana, abril. 2001. Informe Económico 2000. Havana, maio. 2002. Informe Económico 2001. Havana, maio.

BAUZÁ, Vanessa. 2001. “Cuba's Entrepreneurs Find it Tough...”, Sun Sentinel, 11 de junho.

BRUNDENIUS, Claes. 2002a. "Tourism as an Engine of Growth: Reflections on Cuba's New Development Strategy", Conferência "Cuba: Economía y Desarrollo en la Era de la Globalización", Pontificia Universidad Javeriana and Universidad Complutense, Madri, 4-5 de abril. 2002b. Correspondência com o autor.

CARRANZA VALDÉS, Julio. 2001. "La Economía Cubana: Un Balance Breve de una Década Crítica", University of London-Institute of Latin American Studies: Workshop Facing the Challenges of the Global Economy," 25-26 de janeiro.

CASTRO, Fidel. 2000. "Entrevista concedida a Felipe Mayor, el 28 de enero de 2000", Granma, 22 junho de 2000.

CAWTHORNE, Andrew. 2001. "Private Entrepreneurs a Rare Species in Cuba", Reuters, 6 de junho.

CN CUBA EN NEGOCIOS. 2002. "La UE reorienta su apoyo financiero, pero no lo incrementa". Madri, 6 de fevereiro.

COMITÉ CENTRAL DE ESTADÍSTICAS (CCE). 1991. Anuario Estadístico de Cuba 1989. Havana.

DE JESÚS, Ventura. 2002. "Prevén crecimiento en la producción de crudo para el actual año", Granma, 31 de janeiro.

DEL BARRO MENÉNDEZ, Emilio. 2001. "En el sector de turismo, ni satisfacción ni complacencia", e "Por influjo del turismo, creados o recuperados 250,000 empleos", Granma, 25 e 28 de junho.

ECONOMIC COMMISSION FOR LATIN AMERICA AND THE CARIBBEAN (ECLAC). 1998, 2000a. La Economía Cubana: Reformas Estructurales y Desempeño en los Noventa. México: Fondo de Cultura Económica, $1^{\underline{a}}$ e $2^{\underline{a}}$ edições.

2000b. Balance Preliminar de las Economías de América Latina y el Caribe 2000.

Santiago

. 2001a. Cuba: Evolución Económica Durante 2000. México: LC/MEX/L.465, 21 de maio.

2001b. Balance Preliminar de la Economía de América Latina y el Caribe 2001. Santiago, dezembro. 
fevereiro.

. 2002a. Statistical Yearbook for Latin America and the Caribbean 2001. Santiago, 2002b. Cuba: Evolución Económica Durante 2001. México: LC/MEX/L.525, 6 de

junho.

ESPINO, María Dolores. 2001. "Cuban Tourism: A Critique of the CEPAL 2000 Report". Miami, Trabalho apresentado na 11를 Reunião Anual da Association for the Study of the Cuban Economy, 24 de agosto.

ESPINOSA CHEPE, Oscar. 2002. "La economía cubana evolucionó negativamente en 2001", Cubanet Independiente (Havana), 9 de janeiro.

FERRADAZ, Ibrahim. 2001. Citado por Mario Jorge Muñoz, "El complejo mundo de la locomotora", Granma, 11 de janeiro.

2002. Noticiero Estelar Nocturno, Havana, 31 de janeiro.

FRANK, Marc. 2001. "Se desacelera la economía cubana", Nuevo Herald, 27 de junho. 2002a. "Caída en ingresos obliga a renegociar la deuda", Reuters, 22 de fevereiro. . 2002b. "Cuban Peso Under Increasing Pressare", Forbes, 12 de julho.

GARVE, Lucas. 2001. "El pícaro, el gerente y la corrupción”, CUBANET, 26 de junho.

GONZÁLEZ GUTIÉRREZ, Alfredo. 2001. "Aspectos estratégicos en el perfeccionamiento del modelo de planificación”, El Economista de Cuba, 20 de junho.

GUTIÉRREZ CASTILLO, Orlando. 2000. “Cuba, Turismo y Desarrollo Económico”, La Economía Cubana: Coyuntura, Reflexiones y Oportunidades. Havana: Centro de Estudios de la Economía Cubana/ Fundación Friedrich Ebert, abril: 125-142.

GUTIÉRREZ URDANETA, Luis e Orlando Peñate Rivero. 2000. La Reforma de los Sistemas de Pensiones en América Latina: La Alternativa Cubana. Havana: Editorial Ciencias Sociales.

HENKEN, Ted. 2002. "Condemned to Informality: The Self-employed Operators of Cuba's New Bed and Breakfasts", Cuban Studies 32, a sair.

HOAG, Christina. 2002. "Venezuela to Cuba: Oil Isn't Free", Miami Herald, 25 de maio, C-1-2.

JIMÉNEZ, Eduardo. 2002. "Creciendo a pesar de ...", El Economista de Cuba (Havana), fevereiro.

LAGE, Carlos. 2001. Intervención en la Asamblea Nacional, Granma, 22 de dezembro.

2002. Granma, 4 de março.

LEE, Susana. 2002a. "Incrementar los ingresos y reducir los costos en el turismo", Granma, 5 de março. 2002b. "Suman 321 entidades en Perfeccionamiento Empresarial", Granma, 18 de julho. 
LEÓN, Francisco. 2001. "The Prospect of Upgrading in Cuba: The European Factor", "Workshop Facing the Challenges of the Global Economy", cit.

MARQUETTI NODARSE, Hiram. 2000. "Cuba Reanimación del Sector Industrial”, Revista Bimestre Cubana, No. 13, Julho-Dezembro: 5-30.

. 2002. "Cuba: Importancia Actual del Incremento de las Exportaciones", La Economía Cubana en 2001. Havana: Centro de Estudios de la Economía Cubana/ Friedrich Ebert Stiftung, abril:168-171.

MESA-LAGO, Carmelo. 1998. "The Cuban Economy in 1997-1998: Policies and Performance", Cuba in Transition. Washington D.C.: ASCE, Vol. 8: 1-8.

2000. Market, Socialist and Mixed Economies: Comparative Policy and PerformanceChile, Cuba and Costa Rica. Baltimore: Johns Hopkins University Press.

. 2001a. "The Resurrection of Cuban Statistics", Cuban Studies, 31: 139-150.

2001b. "The Cuban Economy in 1999-2001: Evaluation of Performance and Debate on the Future", Cuba in Transition, vol. 11. Washington D.C. ASCE: 1-17.

2002. "La Seguridad Social en Cuba en el Período Especial: Diagnóstico y Sugerencias de Políticas en Pensiones, Salud y Empleo." Santo Domingo: Friedrich Ebert Stiftung, a sair.

MINISTERIO DE FINANZAS Y PRECIOS (MINFO). 2001. Presupuesto del Estado Proyecto 2002. Havana.

MINISTERIO DE SALUD PÚBLICA (MINSAP). 2000, 2001. Anuario Estadístico 1999, 2000. Havana.

EFECOM. "Ministro dice esta cosecha una de las más difíciles en los últimos años." 2002. Havana, 18 de fevereiro.

MONREAL, Pedro. 2001. "Export Substitution Industrialization in Cuba", Workshop Facing the Challenges of the Global Economy," cit.

MONTIEL ORTEGA, Leonardo. 2001. Convenio Petrolero Cubano Venezolano. Una Rectificación Indispensable. Caracas.

MUÑOZ, Mario Jorge. 2001. "El complejo mundo de la locomotora", Granma Nacional (www.granma.Cubaweb.cu), 11 de janeiro.

NOVOA GONZÁLEZ, Armando. 2001. "Las Unidades Básicas de Producción Cooperativa y las Granjas Cañeras entre 1993 y el 2000", La Economía Cubana en el 2000: Desempeño Macroeconómico y Transformación Empresarial. Havana: Centro de Estudios de la Economía Cubana/Fundación Friedrich Ebert, abril: 59-72.

NÚÑEZ BETANCOURT, Alberto. 2002. "Vital incrementar la productividad para alcanzar mayor competencia”, Granma, 18 de fevereiro.

OFICINA NACIONAL DE ESTADÍSTICAS (ONE). 1999. Anuario Estadístico de Cuba 1997. Havana. 
OPINIÃO PÚBLICA, Campinas, Vol. IX, no 1, 2003, pp. 190-223

2000. Anuario Estadístico de Cuba 1999. Havana.

2001. Anuario Estadístico de Cuba 2000. Havana.

2002. Panorama Económico y Social 2001. Havana.

ORRIO, Manuel David. 2001. "Mitos de la educación superior", CUBANET, 19 de junho.

PÉREZ-LÓPEZ, Jorge. 2002. "El Sector Externo de la Economía Cubana", Conferência "Cuba: Economía y Desarrollo en la Era de la Globalización", Pontificia Universidad Javeriana y Universidad Complutense, Madri, 4-5 de abril.

PÉREZ VILLANUEVA, Omar Everleny. 2000. "Estabilidad Macroeconómica y Financiamiento Externo: La Inversión Extranjera Drecta en Cuba”, La Economía Cubana: Coyuntura, cit: 17-41.

2001. "Ciudad de Havana: Desempeño Eonómico y Stuación Social", La Economía Cubana en el 2000 ..., cit.: 35-58.

2002. "La Evolución de la Economía Cubana en los 90s: Una Valoración", Conferência "Cuba: Economía y Desarrollo en la Era de la Globalización", Pontificia Universidad Javeriana y Universidad Complutense, Madri, 4-5 de abril.

PORTAL, Marcos. 2001. Ministro da Indústria Básica, citado em "Esperan producción récord de níquel en el 2001“, Nuevo Herald, 17 de junho.

"Quiet Deal Funds Cuba with Venezuelan Oil." 2002. Stratford, 6 de fevereiro.

REUTERS. "Foreign Investment in Cuba Falls", Havana, 8 de julho.

RITTER, Archibald R. M. 2002. "Cuba: 'Dollarization' and 'De-Dollarization”, Conferência "Cuba: Economía y Desarrollo en la Era de la Globalización," Pontificia Universidad Javeriana y Universidad Complutense, Madri, 4-5 de abril.

RODRÍGUEZ, José Luis. 2000. Report on the Cuban economy, Granma, 23 de dezembro: 1, 5. 2001. Intervención en la Asamblea Nacional, Granma, 22 de dezembro.

RODRÍGUEZ CASTELLÓN, Santiago. 2001. "Consideraciones sobre el Sector Energético Cubano", La Economía Cubana en el 2000, cit.: 18-34.

SCHWEIMLER, Daniel. 2002. "Sugar and Tourism a Bitter Pill on Cubans", Financial Times, 9 de julho.

TRIANA CORDOVÍ, Juan. 2000. “La Economía Cubana en 1999”, La Economía Cubana: Coyuntura, cit.: $1-16$.

cit.: $1-17$. . 2001. "La Economía Cubana en el Año 2000”, La Economía Cubana en el 2000, 
2002. "La Economía Cubana en 2001, una Perspectiva Global”, La Economía Cubana en 2001. Havana: Centro de Estudios de la Economía Cubana/ Friedrich Ebert Stiftung, abril: 18.

TOGORES GONZÁLEZ, Viviana. 1999. "Cuba: Efectos Sociales de la Crisis y el Ajuste Económico de los 90s", Balance de la Economía Cubana a Finales de los 90s. Havana: Centro de Estudios de la Economía Cubana, março: 82-112.

UNITED NATIONS DEVELOPMENT PROGRAM (UNDP/PNUD). 2000. Human Development Report 2000. New York: Oxford University Press.

URIBE, Juan. 2002. "Se agudiza la escasez de petróleo”, Carta de Cuba (Havana), 12 de março. 